\title{
An economic analysis of book Haram's activities in the Chad-Cameroon-Nigeria border area
}

\author{
Isaac Tamba $\mathrm{a}^{*}$ \\ a Faculty of Economics and Management Sciences, University of Yaounde II, Cameroon \\ and Centre for Research on Sustainable Development in Africa (CREDDA) \\ ${ }^{*}$ Corresponding author's e-mail: isatamba@yahoo.fr
}

H I G H L I G H T S:

1. The economic dimension of terrorism can be perceived in the light of factors that motivate terrorists and in terms of the cost of terrorism.

2. An economic system that fails to create opportunities for the poor, excludes them and redistributes wealth in an inequitable manner creates a socioeconomic environment that reactionary groups can take advantage of.

3. Boko Haram is a combination of a sectarian, totalitarian, fundamentalist and above all a political group, especially because it advances the ideal of a fundamentalist Islamist republic well beyond the desire to seize power.

4. The fight against crime and terrorism in all its forms is a global or international public good; in this case, it is necessary to develop a well-coordinated global strategy to address this demand for the global public good.

\section{Article History \\ Received: 02-11-2014 \\ Revised Received: 12-12-2014 \\ Accepted: 28-12-2014 \\ Available online: 06-01-2015 \\ Keywords: \\ Boko Haram; \\ Economic effect of terror; \\ Poverty; \\ International public good.}

JEL Classification:

D06; H04; H05; 001.

\begin{abstract}
Terrorism is fast becoming a worldwide phenomenon with about $25 \%$ of attacks committed in developing countries. These attacks devastate societies causing huge economic loss with negative growth effects. Recent attacks suspectively conducted by Boko Haram in the north of Nigeria and along its border with Cameroon and Chad are already inflicting damage to local economies with a general drop in savings, investment, trade and a strain on domestic budgets. Poverty and exclusion generate dissidents and reactionary groups activities such as Boko Haram. But, the historical background permits to understand the emergency and the development of some of them. Tackling the Boko Haram threat requires a concerted multinational approach with a key socioeconomic component that incorporates the fact that conflict thrives better in circumstances of poverty and inequality.
\end{abstract}

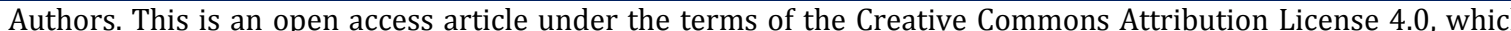
allows use, distribution and reproduction in any medium, provided the original work is properly cited.

\subsection{Introduction}

Hostage-taking, terror campaigns and other forms of terrorist attacks have become commonplace. According to Sandler and Enders (2004), terrorism is the premeditated use or threat of use of violence by individuals or subnational groups to obtain a political or social objective through the intimidation of a large audience, beyond that of the immediate victim. Indeed, notwithstanding wartime attacks, an average of 400 national and transnational terrorist acts are committed yearly with a quarter of these occurring in developing countries. These attacks cause significant human casualty and enormous material damage in societies. According to Frey and al. (2005), terrorism

\footnotetext{
$\diamond$ Views expressed in this article are the sole responsibility of the authors. MIR Centre for Socio-Economic Research, USA or anyone affiliated with MIR Centre for Socio-Economic Research are not responsible for any consequences that ensue for the opinion expressed in the paper. Any paper is published based on the opinion of the blind peer reviewers.
} 
is mankind's scourge of the $21^{\text {st }}$ century. Beyond the loss of human lives and other disasters, acts of terrorism also have financial ${ }^{2}$ and economic consequences. The economic dimension of terrorism can be perceived, first, in the light of factors that motivate terrorists and secondly in terms of the cost of terrorism. The primary motivation driving terrorists is rarely economic ${ }^{3}$. However, an economic system that fails to create opportunities for the poor, excludes them and redistributes wealth in an inequitable manner creates a socioeconomic environment that terrorists can take advantage of. But, the improper definition of justice by powerful nations in the world and inflicting harm on the weaker (i.e. Palestine, Iraq and Afghanistan for example) are one of the reasons for the growing dissidents leading to group like Boko Haram, if not Boko Haram in particular. Moreover, the rulers of Muslim world who play by the western rules and secure their future not their citizens can easily be seen as melting pot for such reactionary groups. In the same way, the wholesome destruction of Iraq, Afghanistan, Libya, etc. are serious recipe for the breeding grounds for reactionary groups.

The fallouts of acts of terrorism contribute to a drop in investment, both domestic and foreign, deterioration in the business environment and greater uncertainty. It also creates distortions in the resource allocation process by influencing consumption, production and saving attitudes. Terrorism thus brings about multidimensional consequences. Correspondingly, the fight against terrorism requires substantial resources that create budgetary displacement effects at the expense of other sectors. Mobilizing and redistribution of resources are likely to engender costs (direct and opportunity). In other words, terrorist acts have negative effects on the process of socioeconomic development ${ }^{4}$. Sometimes, the recession will be deeper or longer (Baily, 2010).

There is no doubt that the terrorist acts orchestrated recently along the Chad-Cameroon-Nigeria border by Islamist sect Boko Haram ${ }^{5}$ have economic consequences. These consequences which are likely to negatively affect the development programs in these countries are either direct or indirect; can manifest with immediate, mid-term and long-term effects and can be of a microeconomic or macroeconomic nature. As diverse as it is in nature, the Boko Haram crisis calls for an immediate response. But also, it calls for long-term preventive, situational and institutional measures, some of a structural nature, to deal with attempts at seducing and enlisting the population into the cause defended by these extremist theories with religious overtones. In any case, the fight against Boko Haram constitutes an additional burden on the budgets of the States concerned. This situation can compel the respective public authorities to respond by raising budget deficits or by raising taxes which both have negative effects on growth.

This paper begins by presenting the Haram and its underlying motives. It then proceeds with an assessment of the real and potential costs of its terrorist activities and concludes with proposals for possible solutions to mitigate, if not contain, the consequences of these terrorist acts.

The first core message of this paper is, poverty and exclusion generate dissidents and fundamentalist groups activities such as Boko Haram. The analysis will try to show that the localities where this group operates are renowned poor in the countries concerned. The second message is, the economic cost of dissident activities is high and much more in midterm, if urgent and appropriate measures are not taken in time, not only to deal with the threat and improve the living conditions of the exposed populations, but reassure the investors, set back confidence and avoid the economy collapse. The other message is to fight against Boko Haram; public expenses for domestic security and military activities respectively fixed at 146 million and 150 million dollars in 2013 and 2014 will considerably increase in Cameroon and certainly, in the two other countries in 2015. That's also the case of the private sector expenses needed to improve the security of their equipment and staff, most of them being foreigners. Such an orientation could exclude the creation of direct productivity activities and increase the cost of labor and capital for the benefit of military activities. Finally, the last message of this paper is to examine the importance of the public good notion, seen from the perspective of the fight against dissident groups such as Boko Haram. Indeed, there's a need for the international community in general and the countries concerned in particular, to coordinate and better address this issue, which is a cross-border problem and includes many countries.

\subsection{What is Boko Haram}

Boko Haram, by its Hausa name, or Sunni group for teachings and is a Nigerian religious movement classified by many countries as a terrorist organization, qualified as a sect by some and as an Islamist insurgent movement by others. Founded in 2002 by Mohammed Yusuf, the organization aims to enforce the strict implementation of Sharia law throughout Nigeria. Moreover, public opinion asserts that Boko Haram is a political organization on account of its Islamic society agenda but also because it bears the fears and hopes of a nation whose construction is unfinished,

\footnotetext{
${ }^{2}$ American analysts place estimates of direct costs accrued from the September 11, 2001 attacks between 25 to 60 billion dollars.

${ }^{3}$ Globally speaking, terrorists are motivated by ideologies: religious, social and political. In most cases, they take religious and political forms.

${ }^{4} \mathrm{~A}$ study comparing the GDP of the Basque country of Spain to the GDP of other regions of the country with the same characteristics but free of terrorism showed that the income per capita dropped by $10 \%$ since 1970 in the Basque regions due to terrorism.

Its ideological stance emphasizes the rejection of Western education. Details will be elaborated in this analysis.
} 
and unveils an ill-legitimized political power (Perugia de Montclos, M-A, 2012). Membership of Boko Haram is now estimated at 30,000 with adherents from Nigeria, Chad and Cameroon 6 .

If Montclos Perugia (2012) calls Boko Haram an organization with "poorly identified goals", it is due to the fact that this organization's ambitions at the confluence of the Salafist Islamist and the Islamist Republican movements. In his opinion, Boko Haram is a combination of a sectarian, totalitarian, fundamentalist and above all a political group, especially because it advances the ideal of a fundamentalist Islamist republic well beyond the desire to seize power.

Initially confined to Nigeria, Boko Haram has been extending its activities around the region since 2012 with hostage-taking and terrorist incursions on Cameroonian and Chadian territory. Following raids in the Far North region of Cameroon, especially in the localities of Fotokol, Makary, Dabanga and Kousseri, the sect has launched an era of abduction since February 2013 beginning with the abduction of a French family, followed by Western missionaries and then ten Chinese nationals in May 2014. Even more dramatic and emotional was the execution of some traditional leaders in these localities of Cameroon.

These recurrent attacks of the Islamist sect have plunged the region into a kind of psychosis ${ }^{7}$, detrimental to the economy and created human and material loss which we seek to appraise in this economic evaluation.

\subsection{The economic costs of the terrorist acts of Boko Haram}

Although it is still early to quantify the actual economic consequences of Boko Haram's terrorist acts, lessons learned from the September $112001^{8}$ attacks in New York provide good measure for understanding the current threat.

First of all, due to the budgetary priority given to security spending, several effects are observable and could justify the budget adjustments, in the three countries concerned, arising from displacement effects or thresholds observed in the management of public finances. These effects reflect the fact that public spending, due to the fight against insecurity, has attained new levels through large budgetary allocations. To this must be added the concentration effect arising due to changes in the structure of public spending on security costs, among others. Most likely is the occurrence of crowding effects or diversion of funds. This may cause slowdown in the execution of certain major investment projects due to the huge sums allocated to fight Boko Haram. In this light, it is possible that the agenda of certain major projects initiated by the government, international donors and the private sector like the tarring of the Waza -Dabanga road in the far North region of Cameroon by Chinese firm Sinhydro could be revised or postponed. This also holds true for the construction of the railway line linking Cameroon to Chad, whose agenda can no longer be met due to the prevailing insecurity in the border area between the two countries.

Other effects may be observed in the short term on the behavior of economic agents towards consumption and savings. The slowdown in economic activity induced by repeated attacks by the sect causes a vicious cycle that brings about a decrease in consumption which in turn reflects a decline in production ${ }^{9}$.

Furthermore, another direct consequence of the activity of Boko Haram is the expected decline in fiscal revenue. Indeed, the higher risk perception, on the one hand and the increased transaction costs on the other hand, are likely to affect international trade in general and bilateral trade between Nigeria and Cameroon in particular. Already, early data reveal an expected drop in Customs revenue in the northern part of Cameroon - entry point for trade with Nigeria, Cameroon's biggest trade partner in Africa ${ }^{10}$. Also worthy of note is the fact that the indirect costs of Boko Haram activities are more visible in the more vulnerable service sector in general (railway transport, air travel, tourism, etc.). Losses currently affecting this industry are mainly due to changes in the structure of consumer demand as well as changes in the consumption pattern of companies (private and public) and the consumption of public administrations. All these consumers are adjusting preferences as the feeling of vulnerability becomes more acute. Regarding tourism which is considered a barometer of social stability for investors, it has been shown that the frequency of terrorist acts brings about a decrease in tourist visits ${ }^{11}$.

\footnotetext{
${ }^{6}$ In September 2014, Boko Haram dissidents seized cattle belonging to Chadian grazers

${ }^{7}$ An example was the spectacular abduction of 200 schoolgirls in Nigeria in 2014.

${ }^{8}$ According to the IMF's "World Economic Report" of December 2001, expenditures directly linked to the September 11 attacks were evaluated at 21.4 billion dollars subdivided as follows: 1) Cost of replacing buildings, equipment and software: $\$ 16$ million (\$14 million being for private sector); 2) Other insurance costs: $\$ 5.2$ million ( $\$ 2.6$ million for life insurance and $\$ 1.8$ million as compensation to employees). The $\$ 21.4$ million spent represents $1 \%$ of the annual Domestic Product. An extra $\$ 4.8$ million covers the cost of stepping up security at airports by the federal agency. This yielded a total expenditure of $\$ 26.2$ million representing an equivalent $7 \%$ of the $\$ 379$ million military budget in the $2002 / 2003$ draft budget.

It was observed that during the first Intifada in Israel, the saving rate dropped drastically, decreasing investment in the country to the same degree.

${ }^{10}$ The volume of trade between Cameroon and Nigeria was evaluated at \$ 0.7 billion in 2012 .

${ }^{11}$ It was the case in the Basque country where terrorism caused a 50\% drop in tourist visits (Frey et al, 2005).
} 
The reduction in the volume of bilateral trade between Cameroon and Nigeria is not the direct result of Boko Haram activities. It arises mainly from the political and administrative choice of national authorities to raise transaction costs through the strengthening of border controls or enforcement of certain measures pertaining to bilateral trade.

In the long term, the economic image of Cameroon, Chad and Nigeria is at stake considering that the flow of foreign direct investment (FDI) is largely dependent on the country ratings of international agencies and rankings by the World Bank's Doing Business report. For instance, Cameroon's Standard and Poor's score has remained stable at "B" since 2011 while it's Doing Business ranking has oscillated between 168th place (2011 and 2014), 165th (2012) and 161st position (2013). During the same period (2011 and 2012), FDI to Cameroon fell more than 126 million dollars. In the case of Nigeria, FDI has declined drastically since 2011 from 8025 million dollars to 5564.1 million in 2012, 4373 in 2013 and 3969 in 2014, more than two times below its 2011 level. This bleak outlook is even more preoccupying in light of a study which showed that from 1975/76 to 1991 in Spain, the volume of FDI decreased by $14 \%$ on average leading to a decline in capital formation, transfer of know-how and techniques accompanying FDI. This had a detrimental effect on the growth trend ${ }^{12}$. During the same period, numerous terrorist attacks by the left in Greece adversely affected foreign companies causing an average 12\% drop in FDI in the country.

Summarily, the Boko Haram threat has an obvious economic cost. This is specifically in terms of net and direct costs considering that these terrorist attacks occur in the context of an asymmetry.

\subsection{The right course of action}

Poverty and exclusion are among the main motives for which the population can be complicit in fundamentalist or totalitarian movements, or take up membership in groups like Boko Haram. In as much as security policies engender a drop in economic activity in the countries concerned, causing sentiments of revolt to flourish, so does poverty foster terrorism. The reverse is also true. Wherever economic, social, legal and statutory inequalities develop and persist, there always thrives humiliation, frustration and suppressed revolts. The current terrorist threat from Boko Haram constitutes an asymmetric warfare ${ }^{13}$ waged by a non-State opponent whose base is not a nation-state but an ideology and religion. It is therefore no surprise that the regions where terrorism is rampant in Cameroon are deemed to be those where structural types of poverty prevail. Thus the need to move quickly to address the situation by ameliorating the living conditions of the poorest population that are most vulnerable to religious fanaticism. In this context, recent data from poverty mapping show that in the Far North, North and Adamawa regions of Cameroon, the incidence of poverty is $67.0 \%, 64.3 \%$ and $54.8 \%$, respectively. These figures are well above the national average of $39.9 \%$. There is therefore every reason to concur that the current socioeconomic environment is conducive to attempts at seducing or recruiting followers from the population of these three regions to the doctrinaire and intolerant movement with religious overtones ${ }^{14}$. Moreover, the localities most targeted by the Islamic sect are those where the incidence of poverty is highest: Mayo Tsanaga (73\%); Mayo Danay (71.5\%); Mayo Kani (71\%), etc.

As concerns Nigeria, about $60 \%$ of the population lives below the national poverty line. Life expectancy in the nation is 52 years and the northern region of the country, which is under threat from Boko Haram, accounts for $70.4 \%$ of the poor. As for Chad, poverty affects $55 \%$ of the population, and is concentrated mainly in rural areas where $90 \%$ of the country's poor live. In fact, poverty is more accentuated in the rural South where Boko Haram operates among the majority of the country's poorest (70\%).

The preceding background review gives reason to recall that religious fanaticism which fuels terrorism thrives on poor arid lands, and gathers momentum from despair, suffering or sympathy towards people in misery. It is thus necessary to develop projects and programs of social and community interest that are capable of reducing poverty in these regions. Hence as an immediate measure, Cameroon, like the other countries involved in this struggle, should increase public investment in the most vulnerable zones while organizing campaigns to distribute commodities to benefit the needy. The preferred strategy would be the Highly Labor-Intensive (HLI) approach to create jobs, even if short-lived, to occupy youth whose idleness would be an excuse to join Boko Haram.

Based on the consideration that the fight against crime and terrorism in all its forms is a global or international public good, we equate the recurrence of terrorist acts in these regions to under-investment in this global public

\footnotetext{
${ }^{12}$ Frey et al., 2005

${ }^{13}$ Unlike asymmetry which emphasizes qualitative differences in the means employed, method and values of Boko Haram, dissymmetry indicates a quantitative difference between the belligerent forces; for example, a strong State against a weak State.

${ }^{14}$ It is estimated that since 2014, about half a thousand youth of the Mayo Sava subdivision (Cameroon) have joined Boko Haram.
} 
good $^{15}$. Worthy of recognition is the fact that Cameroon and other countries concerned by this threat produce less of this international public good than would be desired for other countries to also benefit. Boko Haram has taken advantage of globalization ${ }^{16}$ and market failures to develop a weapons procurement strategy involving Nigeria, Cameroon and Chad. The coordination difficulties between the three countries have made investment sub-optimal and insufficient towards the production of this international public good - fighting against terrorism. To the extent that the aggregate demand for this global public good exists and that national governments (supply) only tend to react when the crisis worsens and costs rise, it is necessary to develop a well-coordinated global strategy to address this demand for the global public good. Although Cameroon is destroying the logistics base of the sect in its territory, it must encourage and strengthen attempts towards ongoing collaboration between the intelligence services of the three countries affected by the terrorist movement. Two intelligence centers have been created to fight against the Islamist sect: the first in Abuja, at the request of France, the United Kingdom and the United States, in order to centralize and process information collected in Cameroon, Chad, Niger and Nigeria. The second recently opened in Kousseri in the Far North of Cameroon, with the mission to facilitate a quick decision based on the information gathered locally.

In general, it is vital to work towards a more proactive policy that helps combat the sources of terrorism including the identification of the sources of its funding ${ }^{17}$. In the other hand, the immediate imperative is to restore confidence and bolster demand, and good policies have already been followed to do this (Baily, 2001). Seen as a global public good, the fight against Boko Haram must therefore be eligible for support from developed countries to finance job-friendly projects, training and facilitate the economic and social integration of people most likely to engage in terrorist activities. A good target group in this regard would be young people without formal education or graduates without real economic prospects (Galbraith, 2002).

Thus, the growth in terrorism and the series of security responses from the countries concerned would guide discussions towards the inclusion of security in development plans and programs in the interest of long-term economic security. This calls for more rational and concerted collaboration between public and private stakeholders in development.

\subsection{Conclusion and policy implications}

This paper analyzed in three aspects the consequences of Boko Haram activities in the economy of countries of the cross-border area Chad-Cameroon-Nigeria: The midterm consequences of the related activities over the trade, budgetary and even the regulatory policy of these countries in general and Cameroon in particular, the demonstration of a one-to-one relation between fanaticism, notably religious and poverty; and economic policies to be addressed in order to alleviate the perverse effects of terrorism in these countries. If Boko Haram is now a feared group of activists, it is partly because it recruits its militants and supporters, and operates in localities deemed poor. However, poverty is not the only motivation of groups such as Boko Haram. The historical background permits to understand the emergency and the development of some dissidents groups, notably in countries where the Muslim religion is dominant. Regardless the motivations of these fogy groups, the economic impact of their activities is notable and can be seen through the change in budgetary allocations, exclusion effects of some expenses, concentration effects, etc. But the economic consequences of the activities of these dissidents groups are more noticeable in midterm and show case through the collapse of the concerned countries image and a decrease of private investments. For this purpose, in Doing Business 2015, Cameroon has lost 10 places, and now occupies the 159 rank, in 2014 in the same Doing Business it was ranked 148; Nigeria is 170 over 189 countries, and Chad occupies the 185 rank in 2015. The economic policy measures suggested were organized around the economic concept of global public good, in so far as the fight against the activities of dissident groups is considered as a world public good. Indeed, the sole resources of a country cannot be sufficient to reduce the spread of fogy groups activities and their exponential growth is mainly explained by a low investment of the public global good.

\section{References}

Abadie, A. and Gardeazabal J., 2003. The economic costs of conflict: A case study of the Basque country. American Economic Review, vol. 93 (1): 113-132. http://dx.doi.org/10.1257/000282803321455188

Baily N. M., 2010. Economic policy following the terrorist attack. International Economic Policy Briefs, Institute for International Economics, october, $9 \mathrm{p}$.

\footnotetext{
15 This is a good characterized by its "Cross borderlines", its indivisibility and its diffusion effects. Indeed, the advantages arising from the extermination of Boko Haram will be widely shared, equally, to all inhabitants of the three countries concerned (principle of non-rivalry); in other words, it will not be possible to exclude a given State because it did not contribute financially in the fight (principle of non-exclusion).

${ }^{16}$ In fact, the Boko Haram phenomenon illustrates one of the paradoxes of globalization which allows for the free movement of goods, services, capital, people and arms all around the world.

${ }^{17}$ Tracking the financing of Boko Haram could expose a "dirty money blackening" process
} 
Enders, W. and Sandler, T., 1991. Causality between transnational terrorism and tourism: The case of Spain. Terrorism, vol.4 (1): 49-58. http://dx.doi.org/10.1080/10576109108435856

Frey, S. et al., 2005. L'impact économique du terrorisme, La Vie économique, Revue économique, $\mathrm{N}^{\circ} 11$.

Galbraith, J-K., 2002. Les implications d'une économie de guerre. Problèmes Economiques, $\mathrm{n}^{\circ} 2748$ : 1-3.

OECD, 2002. Economic consequences of terrorism. 24 p.

Pérouse de Montclos, M-A., 2012. Boko Haram et le terrorisme islamiste au Nigeria : une insurrection religieuse, contestation politique ou protestation sociale?, Questions de recherches, $n^{\circ} 40$, juin.

Sandler, T. and Enders, W., 2004. An Economic Perspective on Transnational Terrorism. European Journal of

Political Economy, 20(2), 301-16. http://dx.doi.org/10.1016/j.ejpoleco.2003.12.007

Tabatoni P., 2002. Note sur l'économie du terrorisme d'après les attentats du 11 septembre 2001, Académie des

Sciences morales et politiques, $6 \mathrm{p}$.

Tamba, I., 2002. Après les attentats du 11 septembre 2001 aux Etats-Unis, s'achemine-t-on vers un «libéralisme interventionniste?, Cameroon Tribune, P. 21.

Tamba, I., 2001. Terrorisme et économie, vers un libéralisme interventionniste?. Actes de colloque, Fondation Friedrich-Ebert, Yaoundé, 21 p.

Verdier, T. et al., 2008. Les coûts économiques du terrorisme, Telos, 3 p.

World Bank , 2014. Doing Business 2015, Washington, D.C. 